концептуальних складових сучасного музикознавства. У концепті «пам'ять» в музиці, на думку дослідника, актуалізується «пам'ять розуміння» (творча пам'ять), яка відповідає найвищим художнім смисловим інтенціям та сприяє іх реалізації.

Ключові слова: концепт «пам'ять», смисл, рівні/типи пам'яті, семантична пам'ять, творча пам'ять, діалог, катарсис.

Marik V. B. Subject matter of the concept «Memory» in the modern musicological poetics. This Article provides an overview of the theories of memory existing in the humanities, describes the peculiarities of art and cultural interpretations of this phenomenon. The category and the phenomenon of memory in the interpretation of A. Samoilenko acts as one of the main and most important conceptual components of the modern musicology. In the concept of «Memory» in music, in the researcher's opinion, «Memory of understanding» (creative memory) is being updated, which meets the highest artistic semantic intentions and contributes to their implementation.

Keywords: concept of «Memory», the meaning, levels/types of memory, semantic memory, creative memory, dialogue, catharsis.

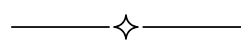

УДК 78.01/.072.3

\title{
В. Іонов
}

\section{ЯВИЩЕ ТЕКСТУ У МУЗИКОЗНАВСТВІ: ДО ПРОБЛЕМИ ІМАНЕНТНОЇ ПРЕДМЕТНОСТІ МУЗИКОЗНАВСТВА}

У статті розглядаються шляхи та способи створення музикознавчого тексту. Відзначаються специфічні риси відтворення смислу у тексті про музику у контексті процесу розуміння. Виявляються складові музикознавчої текстології музики, аналізуються деякі взірці дослідницького типу музикознавчого тексту.

Ключові слова: текст, смисл, розуміння, музикознавство, музикознавче мислення.

Структура загального для музики і музикознавства предмета утворюється взаємозв'язком смислу і тексту, здійснюваним за допомогою значень. Текст можна розглядати як «мережу» для вловлювання смислу - але не прямого, а за допомогою формування знакової форми значення. Смисл упредметнюється в знаку; текст як знакова структура відсилає до смислу. Значення завжди між ними: воно не дорівнює

(C) Іонов B., 2014 
смислу, але й обраний знак є лише одна з можливих форм втілення даного значення. Виявлення способу переходу від смислу до значення, від нього - до знака й, зворотним рухом, від знака, що здійснює «спілкування значеннями» (у цьому Л. Виготський знаходить його основну функцію), до смислових обіцянок значення й далі до усвідомлення смислу становить зміст процесу розуміння. Значення виступає узагальненням форми спілкування або «опосередкованим спілкуванням»; «яка форма спілкування, таке й узагальнення», пише Л. Виготський [3, с. 167]. Від себе додамо: пошуки смислу породжують потребу в спілкуванні, спілкування ж, зі свого боку, ініціює ті або інші значення смислу. Між ними встає текст - як провідник від одного до іншого.

Отже, смисл - значення - текст - взаємно рухливі інстанції розуміння, кожна з яких може бути й відправною, і завершальною: все залежить від позиції суб'єкта, що усвідомлює, від його особистісних «завдань» (у тому числі професійних). Форма спілкування знакова, отже, значення можна розуміти і як удосконалювання смислу (способів досягнення смислу) у знаковій формі. Однак саме тому для значення стає непорушним, піднімається до рівня закону правило формування, виведене Виготським, а саме: «Значення відноситься не до мислення, а до всієї свідомості» [3, с. 167]. Значення забезпечує цілісність процесу виявлення смислу, єдність переживання і інтелектуального з'ясування, єдність двох логік - інтуїції і раціоналізації, причому остання завжди виступає деякою редукцією змісту переживання (яке М. Бахтін визначав як «слід смислу в бутті»), страждає неповнотою. Тим часом знакова форма значення і текст, узятий з його знакової сторони, і є раціоналізація значення (значень), обумовлена інструментальною необхідністю свідомості керувати самою собою. Знаки - «штучні знаряддя» (Л. Виготський) свідомості, інструмент відсторонення результатів осмислюючої роботи.

Спрямована до знакового змісту тексту музикознавча свідомість здобуває екстенсивну спрямованість, звертається до зовнішніх детермінантів музичного впливу. У даному напрямку музикознавство набуває прагматичної націленості, оскільки досліджує безпосередньо діючі аспекти музичної семантики. Вивчаючи досвід значень (означень) музикознавець неминуче «інтенсифікується», тобто змушений досліджувати психосемантику свідомості, у тому числі, власного особистісного досвіду переживання-осмислення. «Інтенсивне музикознавство», звернене до психологічних факторів формування значень (а вони основні), зіштовхується з фактом множинності озна- 
чень однієї й тієї ж знакової реальності, тобто з тим, що ми йменували (слідом за В. Руднєвим) «семантикою можливих світів», для якої істотні не тільки закономірні психічні властивості, але й індивідуальні типи їхньго прояву у свідомості, способи зв'язку, аж до виникаючих непередбачено, внаслідок випадкових умов сприйняття та оцінки музичного феномена. Так утворюється своєрідна парасемантика музикознавчого підходу, цілком відповідна тій семантичній «єдності множинного» й «множинності єдиного», яку виявляє музичний текст.

Породжені семіотичною теорією, прагматика та парасемантика музичної (і музикознавчої) творчості сьогодні здобувають помітну самостійність. Перша - у зв'язку з посиленням інтересу до виконавської природи музики у всій сукупності складових музично-виконавського процесу; друга - у силу освоєння та специфікації тенденції «розуміючого знання», похідної від аналітичної філософії та генеративної поетики. Центруючись на проблемі «музичної свідомості» дві дані тенденції можуть забезпечити музичній історіографії право виступати автономною галузевою музикознавчою та музично-культурологічною дисципліною.

Входячи в коло актуальних загальних проблем культури, «зустрічаючись» у цьому колі з іншими гуманітарними дисциплінами, музична історіологія опиняється в діалогічній позиції, для якої типова взаємодія «чужого - свого», «свого - чужого» (типова для породження будь-якого тексту, на що, зокрема, звертає увагу М. Арановський у своєму дослідженні структури й властивостей музичного тексту [1]) і проходить різні фази діалогу: від підпорядкування авторитету суміжних дисциплін («чужому») - через освоєння їхнього логічного апарата й предметного вибору - до самозаконності стосовно них, до перетворення чужих ініціатив у власні, що переважають досягнення дисципліни - вихідного адресанта діалогу. По суті справи про такий діалог, зі своєї точки зору, міркував І. Котляревський, коли характеризував «екстравертність» та «інтравертність» музикознавчої думки (помітимо, прибігаючи до раніше неспецифічної для музикознавства, особливо стосовно музикознавчого тексту, термінологіi). Так, екстравертність, на погляд названого автора, може проявлятися у двох видах - відцентровому й доцентровому. Відцентрова заснована на запозиченні чужого досвіду і його проекції на власні культурологічні проблеми музикознавства; доцентрова означає ріст надмірності власного досвіду і виникнення бажання віддати його іншим. Інтравертна орієнтація формується між двома названими видами екстравертнос- 
ті, пов'язана з переробкою першого в другий. Для сучасного стану музикознавства характерне зростання значення інтравертності, що веде до відновлення ініціативної позиції музикознавства в контексті гуманітарного знання, до заняття їм місця першого, авторитетного суб'єкта міждисциплінарного діалогу [5, с. 12]. У зв'язку із предметом, що цікавить нас, скажемо, що входження у фазу «своє - чуже», зростання «своєї» авторитетності, формування «своєї» музикознавчої текстології на сучасному етапі стають важливими передумовами трансформації міжпредметних зв'язків музикознавства в його інтердисциплінарні інновації.

Для міжпредметного досвіду музикознавства, тобто на етапі його «екстравертного» розвитку, провідними були такі області гуманітарного знання і відповідні діалогу з ним предметні галузі музикознавчої думки:

- філософія, естетика - музика як форма відбиття дійсності, місце музики в сім'ї мистецтв;

- літературознавство - теорія жанру, стилю й композиції, теоретична та історична поетика, мовна комунікація;

- семіотика - природа музичного знака (з перевагою раціонального логіко-синтаксичного підходу);

- психологія - психофізіологічні основи сприйняття музики, музичних здібностей;

- соціопсихологія - стратифікація слухацької аудиторії, реципієнт як суб’єкт соціуму.

Навіть якщо виділені предметні спільності не вичерпують усього обсягу змістовних відповідностей музикознавства та суміжних наук, вони дають змогупомітити їхню провідну рису - опору на об'єктивовані результати творчої людської діяльності, що дозволяє встановлювати досить чітку границю між художніми текстами та життєвою реальністю.

При зростаючій інтердисциплінарній активності музикознавства, що дозволяє йому самому не просто вибирати, але формувати «партнерів по гуманітарному діалогу», намічаються нові предметні орієнтири, що вказують і на нові галузі мистецтвознавчих досліджень:

- аналіз мови з «семантичним акцентом», тобто з акцентуванням уваги на проблемні значення, методологічний ухил - протиставлення музикознавчої логіки іншим формам гуманітарної рефлексії, зіставлення тексту музичного твору і музичної культури як єдиного текстологічного простору музики, зіставлення всієї реальності культури і 
усього тексту музики, що веде до понять гіперреальності (Ж. Бодріяр) та гіпертексту - семантична текстологія музики і музикознавства (що трансформує досвід аналітичної філософіï);

- моделювання процесу породження музичного явища як «ціннісного породження» світу у свідомості, акцентуація особистісних смислів як передодня універсальних цінностей, персоніфікація виконавського процесу, вивчення символіки музики як невербальної звукової знаковості реальності, зосередження на прийомах виразності, більш за все - на артикуляційних (способах породження звуку як художнього феномена), за допомогою яких ідеаційний зміст перетворюється в художній текст - генеративна (або етимологічна) поетика музики (похідна від структуралістської й збагачена діалогічним літературознавством), що включає прагматику музичної творчості (відгалуження семіотичного підходу);

- визначення універсальних смислів (ціннісних центрів) культури та можливостей (множинних) добратися до них музичними шляхами, формування уявлень про «метамузику» культури як про вираження іiі сакральної сутності і іiі історичного призначення, одночасно пошук глибинних психологічних основ, обумовленостей змісту музики як духовного в початковому та вершинному прояві - парасемантика музики та музикознавства, що веде у бік музичної епістемологї̈ (відгук на синтез культурології та психології особистості).

Для інтердисциплінарних тенденцій сучасного музикознавства стає показовою довіра до суб'єктивних факторів творчого процесу, дослідницьких підходів та оцінок, уявлення про музику і культуру як про феномени цілісної психологічної природи, інтерес до змінених станів свідомості як до самоцінних «знаків»-артефактів інших вимірів реальності, що обумовлює стирання межі між породженням тексту і реальністю, зокрема, веде до семантизації феномена тиші - слідом за його особливим означенням у композиторській творчості.

Надзвичайно важливою $є$ поява досліджень, звернених до сьогоденної національної класики композиторської творчості, тим більш, коли це звернення поєднано з рішенням таких провідних музикознавчих проблем, як стильове мислення в музиці та соціопсихологічні чинники творчого процесу в єдності його особистісно-біографічних та культурно-типологічних сторін.

Доля твору невід'ємна від долі митця, але й ця остання зумовлена усім збігом соціоісторичних обставин. Коли йдеться про композитора, то це, насамперед, можливості виконання - оприлюднення 
музичного задуму та його виконавських версій, що суттєво ускладнюються в долі синтетичного музично-театрального твору, який потребує сукупних зусиль виконавців різних спеціалізацій, представників досить відмінних, хоча й споріднених видів мистецтва. Так, в дослідженні Р. Станкович-Спольської виокремлюється у якості головного предмета роботи фольк-опера $Є$. Станковича «Цвіт папороті», чиє входження в сучасне культурне життя було певною мірою важким та суперечливим. Пов'язуючи вивчення суспільно-мистецького контексту створення названої опери з визначенням іiі жанрового генезису, дослідниця, по-перше, значно актуалізує джерелознавчий підхід, тобто відкриває його можливості стосовно сучасної музичної творчості, збираючи та аналізуючи рукописні нотні матеріали, аудіозаписи, виконавські версії, музикознавчі коментарі та розвідки - все, що засвідчує побутування твору та ступінь його культурного усвідомлення; по-друге, розвиває жанрово-стильовий підхід, визначаючи складові явища та поняття оперного неофольклоризму.

Останньому сприяє також широкий історичний підхід до явищ фольклоризму - неофольклоризму - на рівні цілісної художньої культури XX століття, порівняння концепції Станковича і інших видатних українських музичних митців (М. Лисенка, Б. Лятошинського), створення поруч з «великим» культурно-історичним колом «малого» - власного жанрово-стильового контексту творчості композитора шляхом порівняння творчих принципів композитора в оперній та симфонічній галузях.

Особливої уваги заслуговує обговорення явищ нової фольклорної хвилі, виконавського фольклоризму та витоків і тенденцій становлення неофольклоризму в його сучасному жанрово-стильовому значенні. Так, Р. Станкович-Спольська визначає дві зустрічні тенденції в неофольклоризмі: «академізацію фольклору» та «фольклоризацію академічної традиції», в даному випадку - оперного жанру, надаючи перевагу останній як визначальній та типовій для сучасного композиторського мислення [6, с. 3]; з такої позиції й пропонується аналіз фольк-опери $Є$. Станковича, в якій виявляються «художні типи високого етично-естетичного гатунку» [6, с. 7]. Визначаються нові аспекти символізації оперної форми - як символізації певних оперних структур, що мисляться як цілісні сценічно-музичні побудови. Взагалі аналіз твору Станковича, з одного боку, свідчить про його синтетичне розуміння та відтворення жанрової моделі сучасної фолькопери, з іншого - про переважно музичну ідею твору, що сягає і іiі 
сценографічної «поверхні». Тому на усіх рівнях музичного тексту опери - на структурно-композиційному, тематичному, стилістичному мовному - відкривається поліфонічність мислення композитора - в широкому семантичному значенні цього поняття, а також поліпластовість як провідна риса драматургії твору.

«Знаковість» аналізованого твору для української сучасної музичної культури дозволяє авторці виходити на високий рівень узагальнень стосовно національного стилю, тим самим роблячи суттєвий внесок в теорію національного стиля в музиці, що $є$, безумовно, дослідною парадигмою українського музикознавства (про що свідчать роботи, перш за все, С. Тишка). Інноваційний сенс цієї сторони дисертації багато в чому зумовлений дослідженням національного стилю з боку його «генетичного авторського забарвлення», за висловом самого $\mathrm{C}$. Станковича [6, с. 14], а також розвитком поняття про «фольклорний пріоритет мислення композитора на всіх рівнях творчого задуму - від ідейного змісту до нюансів композиторської технології» (там же).

Надзвичайно цікавим і справедливим здається нам висновок дисертантки, що набуває критичного соціоестетичного значення, а саме: «фольк-опера (Станковича - В. І.) продовжує існувати в сучасному музично-театральному процесі не стільки завдяки версіям-редакціям, а, скоріше, всупереч їм» [6, с. 14].

Інший тип музикознавчого тексту знаходимо у дисертації Т. Бринь. Матеріал цього дослідження постає самостійною завершеною науково-теоретичною конструкцією, а деякі з його ідей могли б слугувати проблематиці окремого дослідження, зокрема, ідея категоріальної єдності науки та мистецтва в культурі середньовіччя, вияв прогностичних тенденцій рубіжної культури Ars Nova, що сягають нашої сучасності, тобто передбачення проблем музичної науки і музичної практики XX-XXI ст., визначення візуальної сторони музичних композицій як невід'ємної частини музичного тексту, коли «текст (графічний) був унікальним сам по собі» [2, с. 96], що також веде до паралелі з композиторської поетикою XX-XXI ст., а вияв «поєднання різночасових моментів в одній композиції», тобто політемпоральності, множинності художнього пізнання та осмислення часу в одному творі, може проекуватись не лише на музичну творчість, а й на літературу, живопис, кінематографічне мистецтво, сучасності.

Дійсно, доба Ars Nova є певним вибухом культуротворчих ідей, що зберігають свої потенціальні можливості до нашого часу, в тому 
числі в музичній теорії, вперше встановлює зв'язки між двома блоками - блоком науки і блоком мистецтва. Ця доба закладає основи теорії знаку, що може бути визнаною водночас початком семіотичної науки; здається симптоматичним це поєднання тенденцій пізнання на «зламі століть» як перебудові типу мислення. А питання про чистий вільний знак («знак без значення»), обговорення протиставлень «континуальне - дискретне» є передбаченням, перше, теорії симулякра і взагалі проблеми знакової артефактності мистецтва у XX ст., друге - вже визнаного сьогодні музикознавчого підходу, запропонованого В. Холоповою, до параметрів експресії в музиці XX-XXI ст.

Окрім сказаного, теоретичні та аналітичні розробки Т. Бринь можна назвати помітним внеском в історію та теорію музичної нотації - 3 наголосом на тих іiї аспектах та проблемах, що є суттєвими для сучасної композиторської творчості, тобто певним чином відроджуються - повертаються - на нашому «зламі часів». Тому ми повністю погоджуємось 3 наступним висновком Т. Бринь: «...Ars Nova $є$ більш ніж просто нова музична школа. Діяльність Ars Nova стала особливою фазою унормування музичного письма в історії музики» [2, с. 109]; додамо: теоретичного унормування, насамперед, тобто унормування на засадах проблеми нотації, наукового самовизначення теорії музики. Паралелі між добою Ars Nova та нашим сьогоденням викликають питання дещо риторичного відтінку. Чи можна вважати, що усі перехідні епохи схожі одна на одну, або це особливі збіги в часі, що стосуються саме великого діалогу культур між Ars Nova та сучасною культурною свідомістю? Чи не дають ці збіги можливість пояснення специфічної тенденції сучасної культури, яку можна назвати, користуючись термінологією дисертації, поверненням з часу Купця до часу Церкви, тобто з часу кількісного до часу якісного - з настійливою суперечкою між названими часами як наслідком зіткнення суто раціонального, з елементами механістичності, та осмислюючого цілісного відношень до світопобудови?

Дослідження зумовлює також важливий категоріальний статус поняття перехідності, що робить рель'єфним теоретичний контур всього дослідження, апелюючи до фундаментальної розробки проблеми перехідності, з відповідним залученням термінології, в роботі Н. Герасимової-Персидської [4].

Аналітичний підхід дозволяє далі розгортати концепцію дослідження, підсилюючи вже увагу до явища простору, при визначенні семантики площинного та об'ємного типу музичних викладів, лі- 
нійних та крапкових способів організації фактури, кількамірності та одномірності музичної структури. Таким чином виокремлюється, як вже музично-специфічне явище, фактура в ії головних координатах. Важливими надбаннями стають аналіз вербального контрапункту як необхідної складової поліфонічного музично-поетичного твору, вияв поліпропорційності та інтертекстуальної гри як чинників полісемантики мотету, що стає його жанровою ознакою, як продовження попередньої позиції - вияв політемпоральності, тобто синтезу різних вимірів часу, в месі Машо. Значну кількість аналітичних знахідок виявляє розгляд маньєризму як важливого етапу автономізації музичного звуку, а разом з ним - музичного знака, зокрема, міста й значення синкопи в теорії та практиці музики [2, с. 161].

Звернемо увагу на цитування Т. Бринь вислову Ю. Лотмана про «мистецтво як форму мислення». Нам здається, що у цього вислову $€$ своя зворотна логіка: мислення стає мистецтвом, набуваючи таких ознак, як краса, витонченість, завершеність та стрункість, знакова автономність, тобто взагалі - мистецькість. Таким і повинне бути справжнє професійне музикознавче мислення.

\section{СПИСОК ЛІТЕРАТУРИ}

1. Арановский М. Музыкальный текст. Структура и свойства / М. Арановский. - М. : Композитор, 1998. - 343 с.

2. Бринь T. ARS NOVA: вимір та раціоналізація музичного часопростору : дис. ... канд. мистецтв. : 17.00.03 / Бринь Тетяна Михайлівна. - Київ, 2005. $176 \mathrm{c}$.

3. Выготский Л. Проблема сознания // Л. Выготский. Собр. соч. : в 6 томах. - М. : Педагогика, 1982. - Т. 1 / [под ред. А. Лурия, М. Ярошевского]. C. $156-167$.

4. Герасимова-Персидская Н. Русская музыка XVII века - встреча двух эпох / Н. Герасимова-Персидская. - М. : Музыка, 1994. - 126 с.

5. Котляревський І. Пріоритетність як фактор розвитку музикознавства / І. Котляревський // Теоретичні та практичні питання культурології: Українське музикознавство на зламі століть : збірник наукових статей. - Мелітополь : Сана, 2002. - Вип. IX.

6. Станкович-Спольська Р. «Цвіт папороті» С. Станковича: проблема жанру : автореф. дис. ... канд. мистецтв. : спец. 17.00.03 «Музичне мистецтво» / Р. Станкович-Спольська. - Київ, 2007. - 18 с.

Ионов В. Явление текста в музыковедении: к проблеме имманентной предметности музыковедения. В статье рассматриваются пути и способы создания музыковедческого текста. Определяются специфические черты вос- 
произведения смысла в тексте про музыку в контексте процесса понимания. Обнаруживаются слагаемые музыковедческой текстологии, анализируются некоторые образцы исследовательского типа музыковедческого текста.

Ключевые слова: текст, смысл, понимание, музыковедение, музыковедческое мышление.

Ionov $V$. The phenomenon of text in musicology: to the problem of immanent objectivity of musicology. The article discusses the ways and means of creating of musicological text. The specific features of the significance reproduction in the text about the music are determined in the context of understanding. The terms of musicological textual criticism is found, some samples of musicological research text are analyzed.

Keywords: text, meaning, understanding, musicology, musicology thinking.

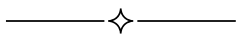

УДК 781.61/781.65

\section{К. Майденберг-Тодорова}

\section{ИМПРОВИЗАЦИЯ КАК СРЕДСТВО ИНТЕРПРЕТАЦИИ} АЛЕАТОРНО-СОНОРИСТИЧЕСКОЙ КОМПОЗИЦИИ

Статья посвящена проблеме интерпретирования современной академической музыки. Выявляется общее композиторско-исполнительское свойство алеаторной и сонористической техник, позволяющее объединять случайное и предустановленное в авторском тексте. В связи с этим предлагается различать импровизацию как самостоятельное музыкальное явление и как основной способ интерпретации современного композиторского текста.

Ключевые слова: интерпретация, импровизация, алеаторно-сонористическая композиция, алеаторика, сонористика.

Современная академическая музыка отличается мультиязычностью, синтетичностью выразительных и архитектонических приемов, разнообразием композиторских техник и авторских эстетических позиций. Однако есть ряд показателей, позволяющих привести эти приемы к общему знаменателю. Целью такого обобщения является определение общих смыслообразующих приемов современной музыкальной композиции и возможных способов ее понимания и интерпретирования.

Проблема интерпретации является одной из наиболее традиционных и устойчивых для современного музыкознания. Ее важность и 